\title{
Cattle Disease Diagnosis Expert System in Bandes Village, Ainaro District
}

\section{Sistem Pakar Diagnosa Penyakit Sapi Di Desa Bandes Kabupaten Ainaro}

\author{
Marito De Oliveira Amaral Barreto ${ }^{1}$, Rina Dewi Indahsari ${ }^{2}$ \\ Program Studi Teknik Informatika, Fakultas Teknologi dan Desain, Institut Teknologi dan Bisnis Asia Malang \\ nito241@gmail.com¹, rinadewi@asia.ac.id²
}

\begin{abstract}
Most of the people in the Bandes village of Ainaro district work as breeders. Cows that are raised are beef cattle. One of the obstacles that exist in Bandes Village is the existence of a few veterinarians in Bandes Village. This research discusses an expert system for diagnosing diseases in cattle, which functions to help determine the disease that is being suffered by cattle, this system will display the results of the diagnosis in the form of the name of the disease, a description of the disease solution and its prevention. In this study there were 4 diseases studied and 7 symptoms. From the 4 disease data, isolation of the problem area, target decision and dependency diagram is made. After that the formation of IF - THEN rules, after the rules are made, the backward chaining process is made. So as to produce a solution to overcome disease in cattle. In program testing is done by comparing the results of the system with experts. In the trials that have been carried out, the results obtained are appropriate or the accuracy of the data and facts obtained from experts on cattle. So based on the results of tests that have been carried out on the system as much as 4 data, the accuracy value obtained is 100\% accurate which shows that the expert system is functioning properly in accordance with the expert's diagnosis
\end{abstract}

Keywords - Expert System, Cows Disease, Bandes Village, Ainaro District, Backward Chaining.

Abstrak. Didesa Bandes kabupaten Ainaro sebagian besar penduduk berprofesi sebagai peternak. Sapi yang dibudidayakan adalah sapi pedaging. Salah satu kendala yang ada di desa Bandes adalah keberadaan dokter hewan yang sedikit di desa Bandes. Penelitian ini membahas sistem pakar diagnosa penyakit pada hewan sapi yang bermaksud untuk membantu menentukan penyakit yang sedang di alami oleh sapi, sistem ini akan menampilkan hasil diagnosa berupa nama penyakit, keterangan penyakit, solusi dan pencegahannya. Pada penelitian ini ada 4 penyakit yang diteliti dengan 7 gejala. Dari 4 data penyakit tersebut dibuatlah isolasi area permasalahan, target keputusan dan diagram ketergantungan. Kemudian dilakukan proses pembentukan aturan (rule) IF-THEN. Berdasarkan rule set yang telah dibuat selanjutnya dilakukan proses backward chaining sehingga dapat menghasilkan solusi untuk mengatasi penyakit pada hewan sapi. Dalam pengujian program di lakukan dengan membandingkan dari hasil sistem dengan pendapat pakar. Dalam uji coba yang telah dilakukan diperoleh hasil yang sesuai nilai akurasi 100\%. Hal ini menunjukkan bahwa sistem pakar berfungsi dengan baik sesuai dengan pengetahuan pakar yang telah di representasikan.

Kata Kunci - Sistem Pakar, Penyakit Pada Sapi, Desa Bandes, Kabupaten Ainaro, Backward Chaining.

\section{Pendahuluan}

Sapi merupakan hewan ternak yang banyak memiliki potensi ekonomi cukup menjanjikan. Banyak sekali manfaat yang di hasilkan oleh sapi, mulai dari daging, susu, kulit, dan tenaganya dapat di manfaatkan oleh manusia. Dagingnya untuk dikomsumsi kemudian diolah menjadi berbagai makanan, susunya sebagai sumber protein yang menyehatkan untuk di konsumsi oleh manusia. Dan tenaganya di gunakan untuk membajak sawah, dibeberapa tempat sapi juga dipakai sebagai alat transportasi.

Didesa Bandes kabupaten Ainaro sebagian besar penduduk berprofesi sebagai peternak. Sapi yang dibudidayakan adalah sapi pedaging. Para peternak sapi di desa Bandes tergabung dalam perkumpulan/koperasi yang mewadahi peternak dalam memenuhi kebutuhan pemeliharaan sapinya. Permasalahan apapun dalam pemeliharaan dan budidaya sapi akan di sampaikan dalam perkumpulan tersebut. Biasanya permasalahannya seputar pakan, pemberian vitamin dan penanganan penyakit. Dalam memelihara sapi, para pemilik sapi di desa Bandes mempunyai pengetahuan yang kurang dalam hal penyakit yang menyerang sapi ternak mereka. Ketika sapi terserang penyakit dan sudah akan mati biasanya pemilik sapi akan segera menyembelih sebelum sapi tersebut mati. Tenaga medis tidak tersedia di desa Bandes hanya di kota Ainaro yang cukup jauh itupun jumlahnya terbatas.

Dokter hewan yang jumlahnya terbatas membuat peternak sapi kesulitan menangani permasalahan kesehatan pada ternaknya. Beberapa kendala diantaranya adalah masalah jarak yang cukup jauh, peternak yang secara mendadak menghubungi dokter yang sedang sibuk mengobati sapi peternak lain, banyaknya panggilan dari peternak dalam waktu yang bersamaan dan di saat libur kerja. Hal ini mengakibatkan banyak sapi sakit yang akhirnya tidak tertolong. Dalam beberapa tahun terakhir angka kematian sapi di desa Bandes terus meningkat 5 sampai 10 sapi yang mati per tahun. 
Sistem pakar adalah sebuah sistem yang dirancang untuk dapat menirukan keahlian seorang pakar dalam memecahkan suatu masalah yang ada [2][4]. Pengetahuan mengenai penyakit sapi disusun mengacu pada literatur dan wawancara dengan dokter hewan di Kota Ainaro. Wawancara yang dilakukan tersebut untuk menggali informasi mengenai penyakit sapi beserta gejala yang dialami serta cara penanganannya. Penentuan penyakit dalam sistem pakar ini dilakukan melalui proses konsultasi antara pengguna dengan sistem dan proses penalaran menggunakan metode Backward Chaining.

Didesa Bandes kabupaten Ainaro sebagian besar penduduk berprofesi sebagai peternak. Sapi yang dibudidayakan adalah sapi pedaging. Para peternak sapi di desa Bandes tergabung dalam perkumpulan/koperasi. Permasalahan apapun dalam pemeliharaan dan budidaya sapi akan di sampaikan dalam perkumpulan tersebut. Biasanya permasalahannya seputar pakan, pemberian vitamin dan penanganan penyakit.

Salah satu kendala yang ada di desa Bandes adalah keberadaan dokter hewan yang sedikit. Di desa Bandes, minimnya dokter hewan yang ada membuat peternak kesusahan saat ternak sapi mereka di serang penyakit, peternak harus mencari dokter hewan lagi di daerah-daerah lain dan tentu ini sangat menyulitkan mereka dan membutukan waktu yang cukup lama. Penanganan pada sapi yang terserang penyakit secara cepat sangat di perlukan oleh peternak, setidaknya, peternak dapat mengetahui jenis penyakit dari gejala-gejala yang timbul dari sapi. Untuk itu, diperlukan sebuah sistem yang dapat di gunakan oleh peternak dalam mendiagnosa penyakit ternak sapi tanpa harus mencari atau menunggu dokter. Terdapat 4 penyakit sapi yang biasanya dihadapi peternak sapi di desa Bandes kabupaten Ainaro. Terdapat penyakit Antarks, Ngorok, Botulismus dan Flu.

Sistem pakar diagnosa penyakit Sapi desa Bandes berfungsi untuk membantu menentukan penyakit yang sedang di derita sapi. Sistem ini akan menampilkan hasil diagnosa berupa nama penyakit, keterangan penyakit serta cara penanganannya. Sistem ini merupakan perangkat lunak yang dapat digunakan untuk membantu menentukan penyakit yang menyerang ternak sapi yang di wujudkan dengan adanya dialog antar pengguna dan sistem. Pada proses ini sistem akan memberikan daftar pertanyaan satu persatu berupa gejala-gejala yang telah dimasukkan dalam sistem berupa basis pengetahuan. Jawaban yang di berikan user akan di proses sehingga menghasikan kesimpulan tentang penyakit yang di derita oleh ternak sapi dan keterangan penyakitnya. Blok diagram sistem secara umum ditunjukkan pada Gambar 1 berikut.

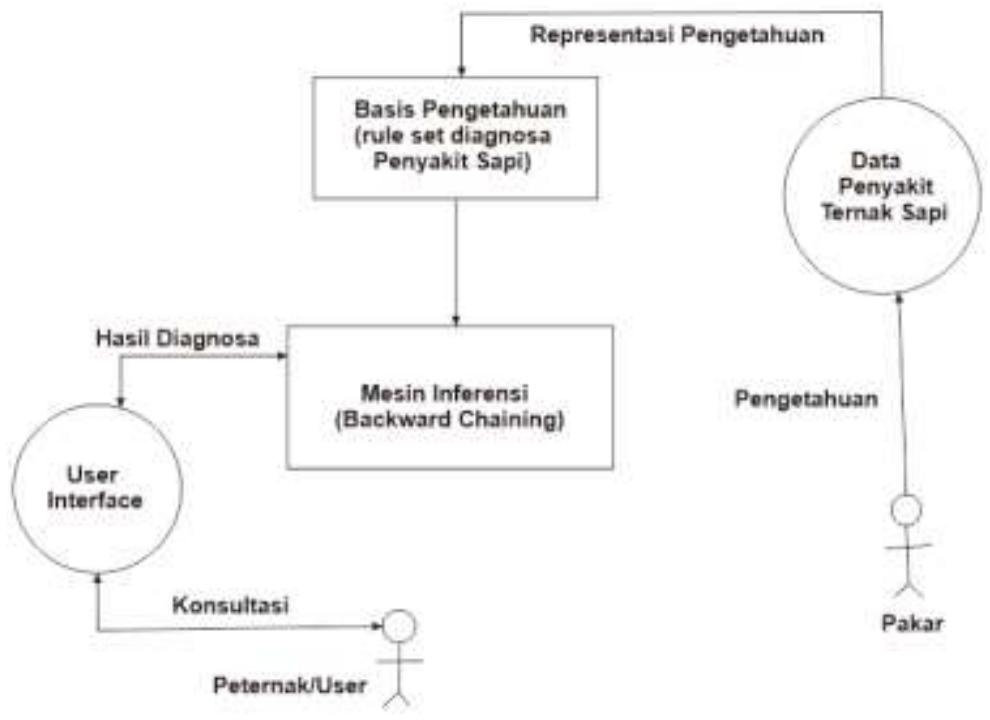

Gambar 1. Diagram Blok Perancangan Sistem Pakar Diagnosa Penyakit Sapi

Dari struktur sistem pakar diagnosa pada penyakit sapi di Desa Bandes Kabupaten Ainaro terdapat data penyakit pada sapi yang di dapat dari pakar Dr Joanico dan data yang didapatkan kemudian direpresetasikan ke dalam basis pengetahuan (Rule set diagnosa penyakit sapi). Setelah itu data yang diolah dari basis pengetahuan akan diproses lagi pada mesin inferensi menggunakan metode backward chaining. Sistem akan menghasilkan kesimpulan diagnosa penyakit berdasarkan fakta yang ada. Jumlah penyakit yang dioalah dalam sistem pakar penyakit sapi adalah 4 macam penyakit yang sering dialami sapi di Desa Bandes Kabupaten Ainaro. Data Penyakit dikodekan sebagai berikut: P001 (Antraks), P002 (Botulismus), P003 (Flu) dan P004 (Ngorok). Dari 4 penyakit tersebut kemudian dianalisa data-data gejala untuk menentukan input atribut dan nilai atributnya yang ditunjukan pada tabel 1.

Tabel 1. Data Atribut dan Nilai Atribut

\begin{tabular}{|l|l|l|}
\hline \multicolumn{1}{|c|}{ Atribut } & \multicolumn{1}{|c|}{ Sub Atribut } & \multicolumn{1}{c|}{ Nilai Atribut } \\
\hline \multirow{2}{*}{ Demam } & Mengeluarkan cairan dari mma & Banyak, Sedikit \\
\cline { 2 - 3 } & Suhu tinggi lebih dari 3 hari & Suhu $>=40 \mathrm{c}$, Suhu $<40 \mathrm{c}$ \\
\hline
\end{tabular}


Procedia of Engineering and Life Science Vol. 1. No. 2 Juni 2021

Seminar Nasional \& Call Paper Fakultas Sains dan Teknologi (SENASAINS 2nd)

Universitas Muhammadiyah Sidoarjo

\begin{tabular}{|l|l|l|}
\hline Pencernahan & Muntah-Muntah & Ya,tidak \\
\cline { 2 - 3 } & Nafsu Makan turun & Makan $<3$, Makan $>=3$ \\
\hline Pernafasan & $\begin{array}{l}\text { Mengeluarkan cairan dari hidung saat } \\
\text { di usap }\end{array}$ & Ya,tidak \\
\cline { 2 - 3 } & Mulut sapi mengangah & Sering, tidak \\
\cline { 2 - 3 } & $\begin{array}{l}\text { Terdengar suara dengkuran saat } \\
\text { bangun }\end{array}$ & Kadang Tidak \\
\hline
\end{tabular}

\section{Perancangan Sistem Pakar}

\section{A. Perancangan Basis Pengetahuan}

Sistem pakar diagnosa penyakit sapi membutuhkan basis pengetahuan untuk membantu menentukan penyakit pada sapi. Basis pengetahuan ini berisi rule set yang merupakan pengolahan dari data gejala-gejala, jenis penyakit, keterangan tiap penyakit, solusi pengobatan dini dan pencegahannya [9]. Ada beberapa langkah dalam membangun knowledge based system (Basis Pengetahuan) yaitu [11][12]:

1. Melakukan Isolasi area Permasalahan

2. Menentukan Target Keputusan

3. Membuat Diagram Ketergantugan

4. Membentuk Tabel kenputusan

5. Membuat Rule IF-THEN

\section{Isolasi Area Permasalahan Pada Penyakit Sapi}

Pembuatan isolasi area permasalahan penyakit pada sapi dimaksudkan untuk membatasi lingkup permasalahan yang di bahahas dengan mengetahui posisi pokok pembahasan pada domain yang lebih luas [5]. Dalam pembuatan isolasi area ini menggunakan blok diagram permasalahan yang mana dalam pembuatan ada 3 gejala penyakit pada sapi. Blok diagram isolasi area permasalahan di tunjukan pada Gambar 2.

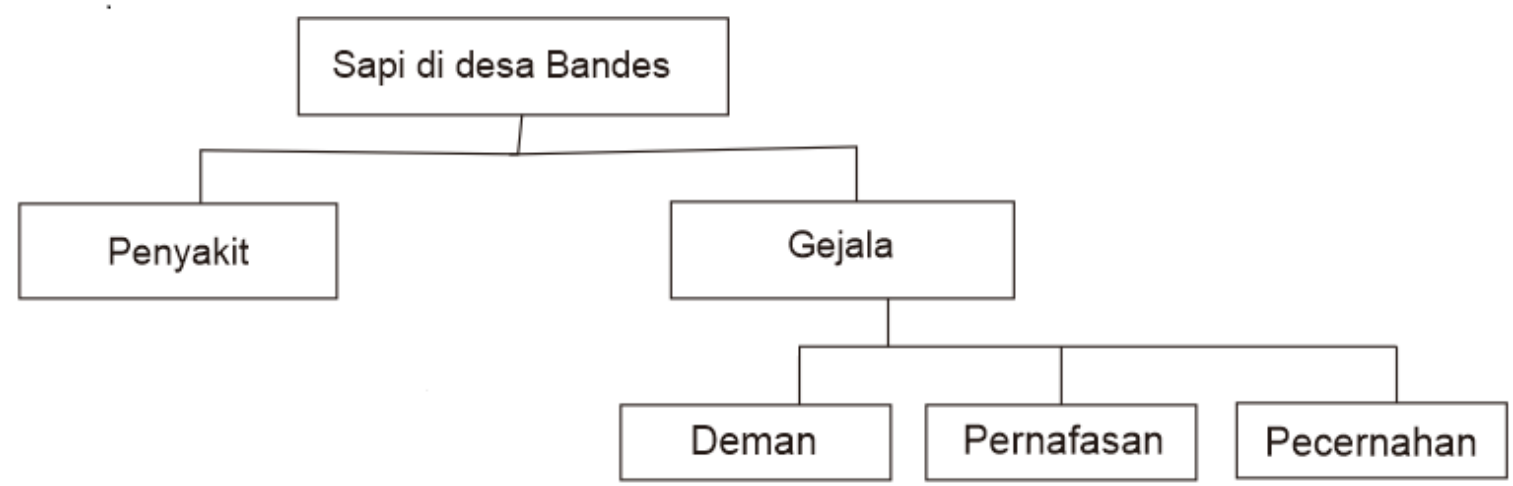

Gambar 2. Isolasi Area Permasalahan Penyakit Sapi

\section{Menentukan Target Keputusan Pada Penyakit Sapi}

Setelah permasalahan dibatasi, langkah selanjutnya adalah menentukan target keputusan bagi sistem pakar [3]. Terdapat 8 target keputusan penyakit pada hewan sapi yaitu: P001, P002, P003, P004, P002 dan P003, P003 dan P004, P002 dan P004, dan Sehat. Penyakit pada hewan sapi tersebut ditentukan oleh 3 hal yaitu demam, pernafasan, dan pencernaan. Ketiga hal tersebut dipengaruhi oleh 7 gejala yaitu G01, G02, G03, G04, G05, G06 dan G07. Diagram target keputusan ditunjukkan pada gambar 3 .

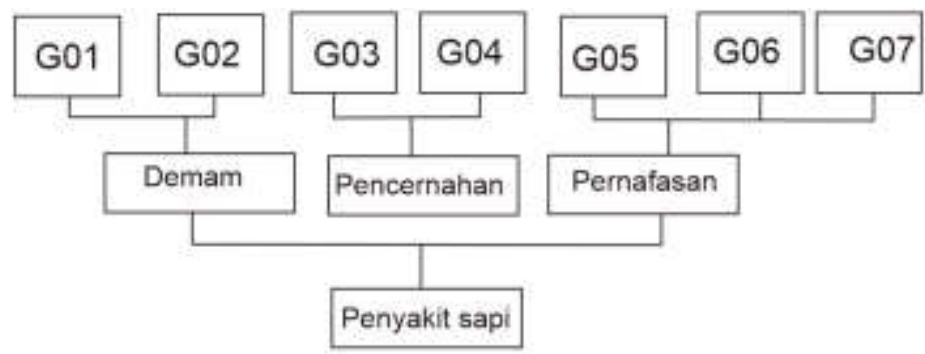

Diagram Ketergantungan

Gambar 3. Target Keputusan Permasalahan Penyakit Sapi 
Diagram ketergantungan merupakan diagram yang mengindikasikan hubungan antara pernyataan, aturan, nilai, dan rekomendasi dari basis pengetahuan [7]. Sasaran pengambilan keputusan yang akan dibuat prototypenya ditransformasi kedalam sebuah dependency diagram [7]. Dalam dependency diagram terlihat ada 3 faktor kritis yang mempengaruhi pengambilan kesimpulan untuk penyakit hewan Sapi. Setiap factor kritis disimbolkan dengan segitiga dan membentuk sebuah rule set. Sehingga terlihat bahwa pada permasalahan diagnose penyakit sapi ini terdapat 4 rule set yang akan dibangun. Set Pertanyaan juga terlihat dari dependency diagram pada bagian paling kiri, yaitu terdapat 7 atribut dengan tanda tanya yang berarti adalah set Pertanyaan dalam user interface nantinya. Diagram ketergantungan ditunjukkan pada gambar 4 .

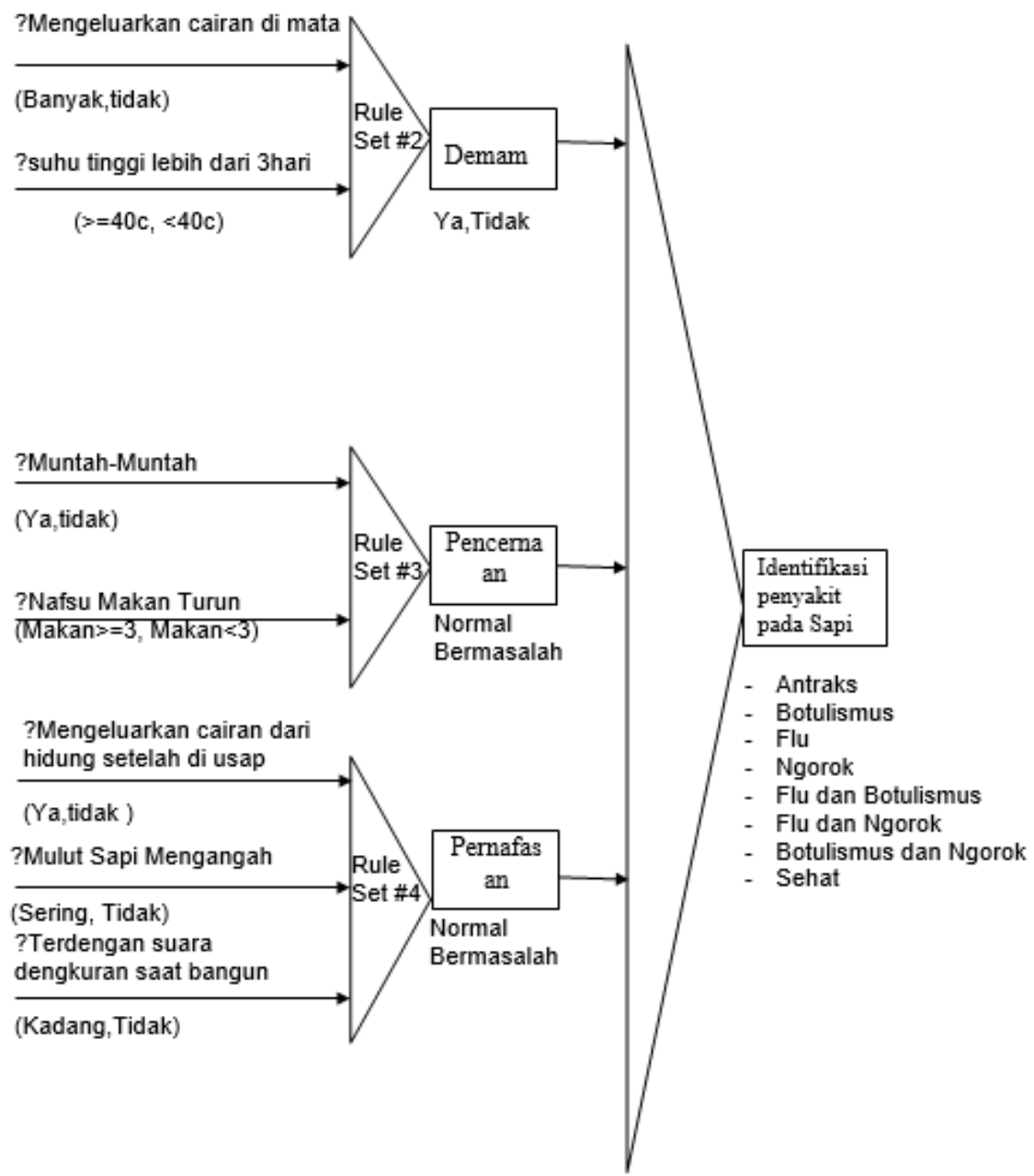

Gambar 4. Diagram ketergantungan Permasalahan Penyakit Sapi

Membentuk Rule

Pembentukan rule melalui 4 tahap sebagai berikut [1][6]:

1. Membuat plan setiap rule set

2. Membuat table keputusan lengkap

3. Membuat table keputusan reduksi

4. Menuliskan rule

Dalam Penelitian ini terdapat 4 rule set yang dibentuk. Masing-masing set memiliki jumlah rule yang berbedabeda yang ditunjukkan pada table 2 .

Tabel 2. Rule Set Permasalahan penyakit Sapi

\begin{tabular}{|l|l|}
\hline Rule \# & Rule \\
\hline R1 & $\begin{array}{c}\text { IF Demam = Ok and Pencernahan = Bermasalah and Pernafasan = Bermasalah } \\
\text { THEN Penyakit= Antarks }\end{array}$ \\
\hline R2 & $\begin{array}{c}\text { IF Demam = Ok and Pencernahan = Bermasalah and Pernafasan = Normal } \\
\text { THEN Penyakit= Flu dan Botulisme }\end{array}$ \\
\hline R3 & IF Demam = Ok and Pencernahan = Normal and Pernafasan = Bermasalah \\
\hline
\end{tabular}


Procedia of Engineering and Life Science Vol. 1. No. 2 Juni 2021

Seminar Nasional \& Call Paper Fakultas Sains dan Teknologi (SENASAINS 2nd)

Universitas Muhammadiyah Sidoarjo

\begin{tabular}{|c|c|}
\hline & THEN Penyakit $=$ Flu dan Ngorok \\
\hline R4 & $\begin{array}{l}\text { IF Demam }=\text { Ok and Pencernahan }=\text { Normal and Pernafasan }=\text { Normal } \\
\text { THEN Penyakit }=\text { Flu }\end{array}$ \\
\hline R5 & $\begin{array}{l}\text { IF Demam = Not_ok and Pencernahan = Bermasalah and Pernafasan = Bermasalah } \\
\text { THEN Penyakit= Botulisme dan Ngorok }\end{array}$ \\
\hline R6 & $\begin{array}{l}\text { IF Demam = Not_Ok and Pencernahan }=\text { Bermasalah and Pernafasan }=\text { Normal } \\
\text { THEN Penyakit }=\text { Botulisme }\end{array}$ \\
\hline R7 & $\begin{array}{l}\text { IF Demam = Not_ok and Pencernahan = Normal and Pernafasan = Bermasalah } \\
\text { THEN Penyakit }=\text { Ngorok }\end{array}$ \\
\hline $\mathrm{R} 8$ & $\begin{array}{l}\text { IF Demam }=\text { Not_ok and Pencernahan }=\text { Normal and Pernafasan }=\text { Normal } \\
\text { THEN Penyakit }=\text { Sehat }\end{array}$ \\
\hline R9 & IF Mengeluarkan cairan dari mata = Banyak THEN Demam= ya \\
\hline R10 & $\begin{array}{l}\text { IF Mengeluarkan cairan dari mata }=\text { Sedikit and Suhu tinggi lebih dari tiga hari }= \\
\text { suhu }>=40 \mathrm{c} \text { THEN Demam }=\text { ya }\end{array}$ \\
\hline R11 & IF Mengeluarkan cairan dari mata $=$ suhu $<40 \mathrm{c}$ THEN Demam $=$ tidak \\
\hline $\mathrm{R} 12$ & IF Muntah-Muntah = Ya THEN Pencernahan = Bermasalah \\
\hline R13 & $\begin{array}{l}\text { IF Muntah-Muntah = Tidak and Nafsu makan turun = Makan }<3 \\
\text { THEN Pencernahan = Bermasalah }\end{array}$ \\
\hline R14 & $\begin{array}{l}\text { IF Muntah-Muntah = Tidak and Nafsu Makan turun = Makkan>=3 } \\
\text { THEN Pencernahan = Normal }\end{array}$ \\
\hline R15 & $\begin{array}{l}\text { IF Mengeluarkan cairan setelah di usap= ya and Terdengar suara dengkuran = } \\
\text { Kadang THEN Pernafasan = Bermasalah }\end{array}$ \\
\hline R16 & $\begin{array}{l}\text { IF Mengeluarkan cairan setelah di usap }=\text { ya and mulut sapi menganga = sering and } \\
\text { Terdengan suara dengkuran = Kadang THEN Pernafasan = Bermasalah }\end{array}$ \\
\hline R17 & $\begin{array}{l}\text { IF Mengeluarkan cairan setelah di usap= tidak and Terdengar suara dengkuran = } \\
\text { Kadang THEN Pernafasan = Bermasalah }\end{array}$ \\
\hline R18 & $\begin{array}{l}\text { IF Mengeluarkan cairan setelah di usap= tidak and Terdengar suara dengkuran }= \\
\text { tidak THEN Pernafasan }=\text { Normal }\end{array}$ \\
\hline R19 & $\begin{array}{l}\text { IF Mengeluarkan cairan setelah di usap= ya and Mulut mengangah = tidak } \\
\text { Terdengar suara dengkuran = tidak THEN Pernafasan =Normal }\end{array}$ \\
\hline
\end{tabular}

\section{B. Perancangan Mesin Inferensi}

\section{User Interface Untuk Sistem Pakar Penyakit Sapi}

User Interface dalam sistem pakar merupakan mekanisme komunikasi antara user (pengguna) dan sistem. User Interface (antar muka) menerima informasi dari user dan mengubahnya dalam bentuk yang dapat diterima oleh sistem dan begitu juga sebaliknya [8]. User Interface juga menerima informasi dari sistem dan menyajikan ke dalam bentuk yang dapat dimengerti oleh user. Dalam user Interface terdapat pertanyaan dan jawaban gejala-gejala dari penyakit sapi yang akan ditanyakan kepada user untuk mengetahui penyakit apa yang dialami oleh sapi tersebut. Pertanyaan dan jawaban terkait gejala yang ada pada sapi di tunjukan pada tabel 3.

Tabel 3. Set Pertanyaan untuk Konsultasi Permasalahan penyakit Sapi

\begin{tabular}{|c|l|l|}
\hline No & \multicolumn{1}{|c|}{ Pertanyaan } & \multicolumn{1}{|c|}{ Jawaban } \\
\hline 1 & Apakah mengeluarkan cairan di mata ? & Banyak;Sedikit \\
\hline 2 & Apakah suhu tinggi lebeih dari 3 hari ? & Suhu $>=40$; suhu $<40 c$ \\
\hline 3 & Apakah muntah-muntah ? & Ya;tidak \\
\hline 4 & Apakah nafsu makan turun ? & Makan<3; makan>=3 \\
\hline 5 & Apakah mengeluarkan cairan di hidung setelah diusap ? & Ya;tidak \\
\hline 6 & Apakah mulut sapi mengangah ? & Sering;tidak \\
\hline 7 & Terdengar suara dengkurang saat bangun ? & Kadang;tidak \\
\hline
\end{tabular}




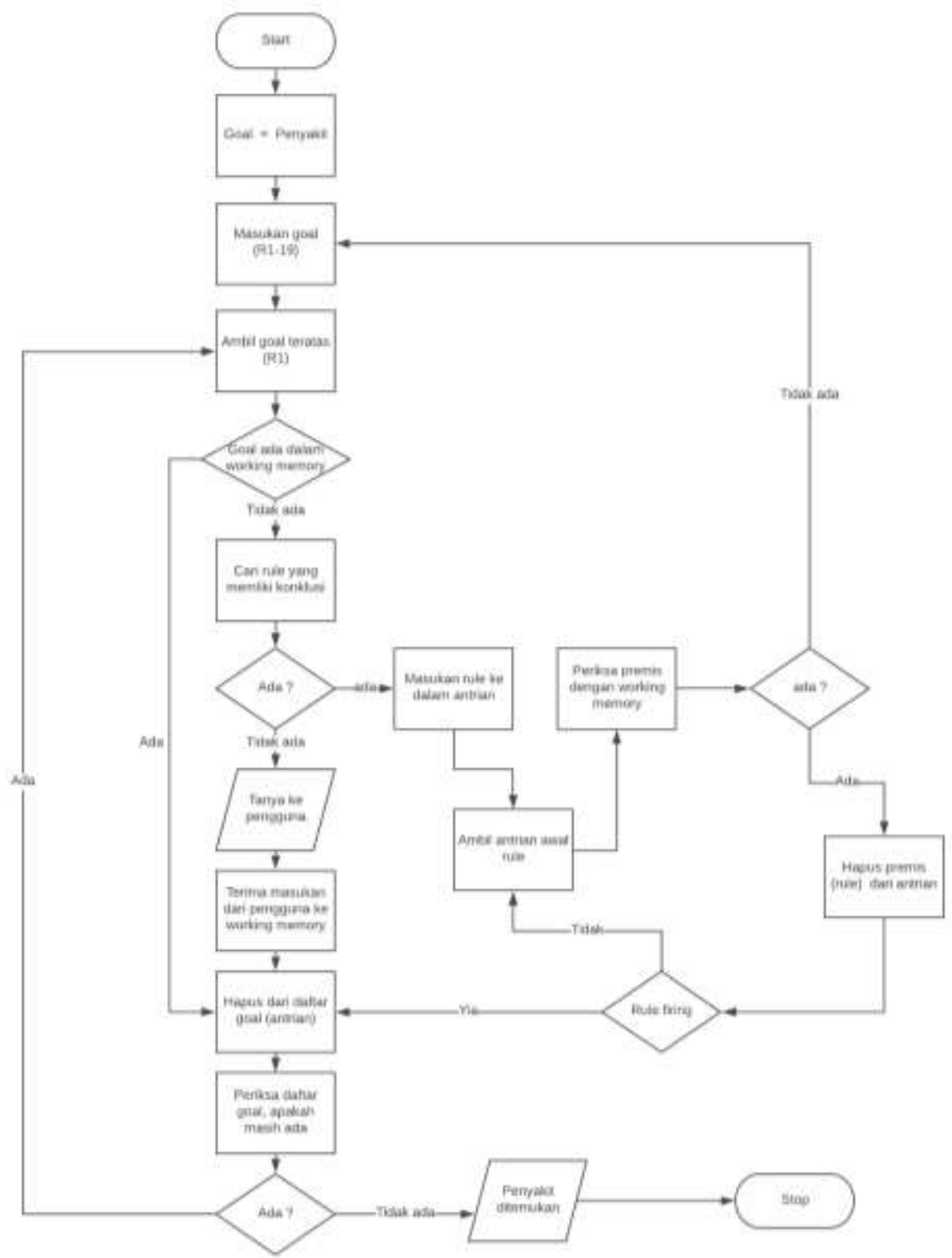

Gambar 5. Alur Metode Backward Chaining Dalam Menarik Kesimpulan

Gambar 5 menunjukkan proses backward chaining penyakit sapi. Dimulai dengan memilih suatu goalnya yaitu penyakit, kemudian sistem memeriksa dengan fakta yang tersimpan dalam working memory. Apabila fakta yang diperlukan tidak ada, maka goal dibandingkan dengan konklusi dari salah satu aturan. Jika aturan ditemukan, maka sistem akan memeriksa premis dari aturan tersebut. Jika fakta dalam premis yang mendukung tidak ada dalam working memory, sistem menanyakan ke pengguna untuk melengkapi fakta yang mendukung premis. Fakta dari pengguna kemudian dimasukan ke working memory. Proses tersebut dilakukan berulang sampai daftar goal kosong dan penyakit ditemukan [10].

\section{HASIL IMPLEMENTASI DAN PENGUJIAN}

Pembuatan program sistem pakar diagnosa penyakit Sapi ini berbasis website, dimana penggunaan webite ini memiliki keunggulan yaitu sebagai media akses informasi yang lebih mudah di akses dimana saja dan kapan saja, 
jika ingin mengetahui penyakit pada sapi. Serta dapat digunakan di berbagai perangkat. Pada program sistem pakar diagnosa penyakit pada sapi terdapat 2 bagian yaitu ada bagian admin dan user. Site map alur program dapat dilihat pada gambar 6.

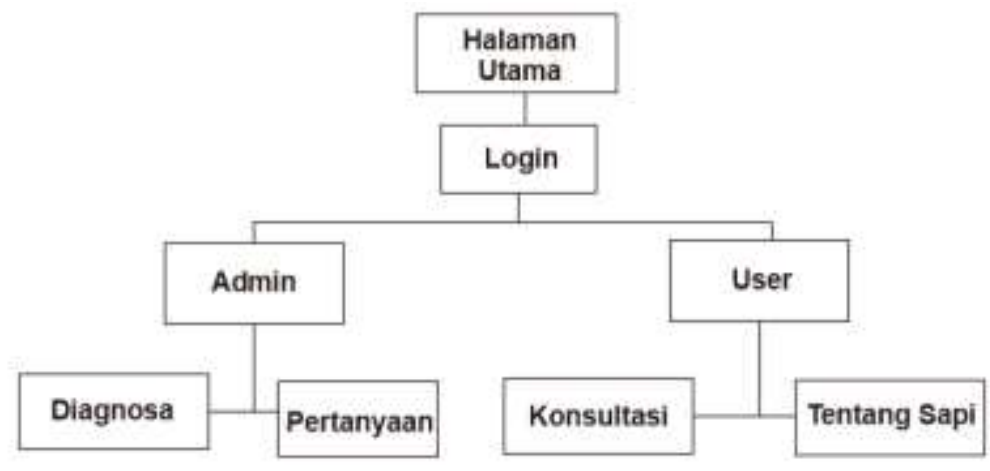

Gambar 6. Sitemap website sistem pakar diagnose penyalit sapi

Proses konsultasi akan dilakukan oleh pengguna sistem yaitu peternak sapi. Untuk pengguna atau peternak sapi dapat langsung mengakses sistem pakar diagnosa penyakit pada pada sapi dengan cara daftar terlebih dahulu. Setelah terdaftar pada sistem selanjutnya dapat melakukan konsultasi dengan memilih menu konsultasi. User akan diberikan satu Pertanyaan, dan Pertanyaan selanjutnya sangat tergantung jawaban yang diberikan oleh user. Jadi dengan fakta yang berbeda, sistem akan memberikan Pertanyaan yang berbeda pula sampai didapatkan kesimpulan dari goal yang dicari. Tampilan sistem untuk proses konsultasi ditunjukkan pada gambar 7.
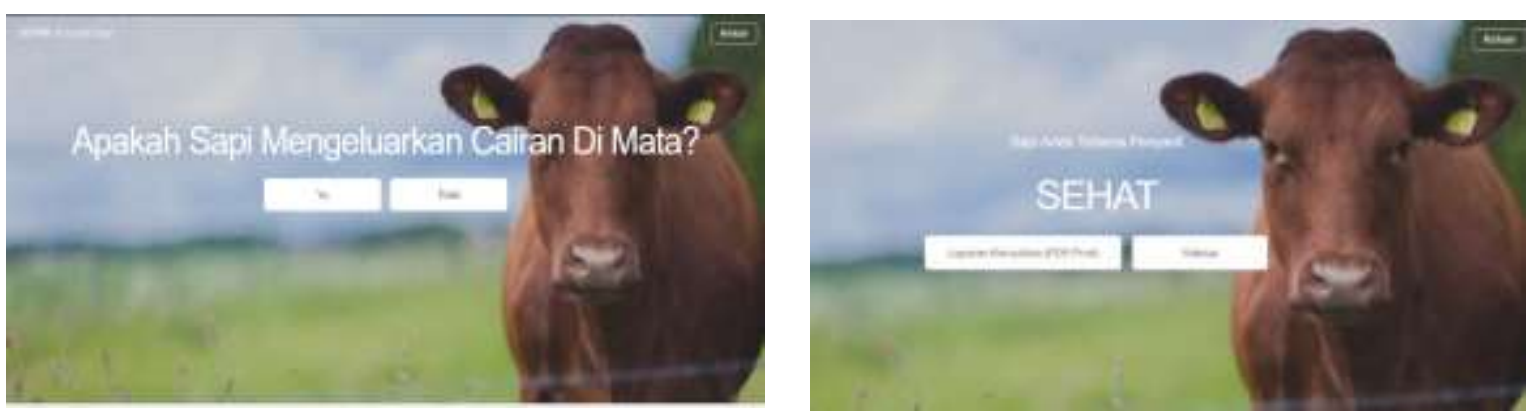

Gambar 7. Tampilan program sistem pakar diagnosa peyakit sapi

Pengujian pada sistem dilakukan dengan melibatkan pakar pada penyakit sapi. Tujuan dari pengujian ini adalah mengukur tingkat kebenaran hasil konsultasi dari sistem yang telah dibuat. Cara pengujiannya dengan melakukan konsultasi dengan inputan yang berbeda dan hasil konsultasinya akan di cocokkan dengan data dari pakar. Terdapat 20 set fakta yang akan digunakan untuk pengujian. Hasil diagnose dari sistem pakar akan dibandingkan dengan pendapat pakar. Dan dalam Penelitian ini diperoleh nilai validasi 100\%, artinya dari 20 set fakta yang dikonsultasikan kedalam sistem telah menghasilkan diagnose yang sesuai dengan pakar.

\section{KESIMPULAN}

Dari hasil Penelitian ini secara umum dapat diambil kesimpulan bahwa proses perancangan sistem pakar membutuhkan proses Analisa yang cukup Panjang dalam menentukan input atribut dan value atributnya. Pembuatan program sistem pakar ini dapat membantu peternak sapi atau user dalam hal pengetahuan tentang penyakit pada sapi serta cara pencegahanya. Hasil pengujian sistem dengan menggunakan metode backword chaining untuk menentukan diagnosa penyakit pada sapi menunjukkan hasil yang baik yaitu $100 \%$ dari 20 set fakta yang diujikan memberikan hasil diagnosa yang sesuai dengan pendapat pakar.

Melihat perkembangan teknologi yang sangat pesat dan telah sangat normal bahkan ke masyarakat pedesaan, maka sistem pakar ini dapat dikembangkan menjadi aplikasi berbasis Android dan bisa diperluas arenya bukan hanya diperuntukkan masyarakat desa Bandes saja. Sangat memungkinkan terdapat penyakit lain diluar 4 penyakit yang dibahas khususnya untuk jenis sapi yang berbeda, karena itu sistem ini dapat dikembangkan dengan menambahkan jenis penyakitnya. 
Procedia of Engineering and Life Science Vol. 1. No. 2 Juni 2021

Seminar Nasional \& Call Paper Fakultas Sains dan Teknologi (SENASAINS $2^{\text {nd }}$ )

Universitas Muhammadiyah Sidoarjo

\section{REFERENSI}

[1] Andriani, Pemrograman Sistem Pakar, Yogyakarta, Mediacom, 2017.

[2] Azmizulfian, Pengantar Sistem Pakar dan Metode, Jakarta, 2017.

[3] Kusrini, Sistem Pakar Ilmu Teknologi, Yogyakarta, Amikom. 2017.

[4] Kusuma Dewi, E, Kecerdasan Buatan Manusia (Artifical intelligence), Yogyakarta, Researchgate.net. 2017.

[5] Merlianan Nita, H. R, Perancangan Sistem Pakar, Jakarta, Penerbit Ghalia Indonesia, 2012

[6] Siswanto, Kecerdasan Tiruan edisi 2, Yogyakarta, Graha ilmu, 2010

[7] Kusrini. Sistem Pakar Teori dan Aplikasi. Andi Yogyakarta, 2006

[8] Farizi, Anif. Sistem Pakar Untuk Mendiagnosa Kerusakan Komputer Dengan Menggunakan Metode Forward Chaining. Jurusan Teknik Elektro, Fakultas Teknik, Universitas Negeri Semarang. 2014

[9] Iriani, Siska. Penerapan Metode Backward Chaining pada Sistem Pakar Diagnosa Penyakit Tulang Manusia. STKIP PGRI Pacitan. 2015

[10] Lestari D. Jurnal: Definisi sistem pakar. Arsip Teknik Informatika UMMI. 2012

[11] Kusrini, Aplikasi Sistem Pakar Menentukan Faktor Kepastian Pengguna dengan Metode Kuantifikasi Pertanyaan, Andi, Yogyakarta, 2008

[12] Nurhasanah, Fujiansyah. Pembuatan Sistem Pakar Untuk Memprediksi Awal Penyakit Gigi dan Mulut Berbasis Web Dengan Metode Backward Chaining. Prosiding Seminar Nasional Ilmu Komputer Universitas Diponegoro. Semarang, 2010 